\title{
Effect of post-harvest treatments on the level of glucosinolates in broccoli
}

\author{
Ana S Rodrigues and Eduardo AS Rosa* \\ Section of Horticulture, Department of Field Crops, Universidade de Trás-os-Montes e Alto Douro, Apartado 202, 5001 Vila Real Codex, \\ Portugal
}

\begin{abstract}
Broccoli is a very perishable vegetable with a high water content (around $88 \%$ ) which leads to rapid dehydration and probably to an alteration in composition if conditions after harvest are not controlled. This study evaluates the glucosinolate pattern and glucosinolate levels in the principal and secondary inflorescences of fresh broccoli cv 'Tokyodome', and after being submitted to some situations which are likely to occur during or after harvest: room temperature $\left( \pm 20^{\circ} \mathrm{C}\right)$ for 5 days, kept in the fridge at $4^{\circ} \mathrm{C}$ for 5 days, and frozen after blanching. Another set of material was harvested 5 days later, simulating a post-maturation stage, and analysed. The highest total glucosinolate content was found at commercial maturation with 20888 and $20355 \mu$ moles $\mathrm{kg}^{-1} \mathrm{DW}$ in the principal and secondary inflorescences, respectively. Keeping the inflorescences at room temperature caused the most significant $(P<0.05)$ reductions in total and individual glucosinolates, except for 4-hydroxyindol-3ylmethyl-, 2-hydroxy-2-phenylethyl- and 2-phenylethyl-, when compared to the other situations. The highest levels $\left(10925 \mu\right.$ moles kg $\left.{ }^{-1} \mathrm{DW}\right)$ of 4-methylsulphinylbutyl-, the precursor of the anti-cancer isothiocyanate sulphoraphane, were found in the inflorescences freshly harvested at commercial stage. Refrigeration at $4^{\circ} \mathrm{C}$ and freezing were shown to be the best preservation processes for maintaining high levels of these and other glucosinolates in contrast with the other situations.

(C) 1999 Society of Chemical Industry
\end{abstract}

Keywords: Brassica oleracea var italica; Brassicaceae; broccoli; composition; glucosinolates

\section{INTRODUCTION}

Broccoli, a member of the Brassicaceae, has been associated with a decreased risk of cancer based on several beneficial properties such as the levels of vitamin C, fibre and glucosinolates, a group of secondary plant metabolites. ${ }^{1-4}$ These compounds, upon hydrolysis by the enzyme myrosinase (thioglucose glucohydrolase EC 3.2.3.1), yield a variety of bioactive products, including isothiocyanates, thiocyanates, nitriles and oxazolidine-2-thiones depending on the chemical structure and the conditions during enzymic cleavage. Glucosinolates and their breakdown products are important aroma and flavour compounds in Brassica vegetables.

Broccoli is a crop which has found increasing popularity. In the USA, production and consumption has increased dramatically ${ }^{5-7}$ since it was demonstrated that the crop contained a glucosinolate precursor of the isothiocyanate sulphoraphane (1-isothiocyanate-(4R)-(methylsulphinyl)butane), a compound with the ability to induce enzymes protective against cancer. ${ }^{8}$ Other glucosinolates, particulary those with indolyl groups, have also been associated with induction of protective mechanisms. ${ }^{9}$
Broccoli is often submitted to long transportation periods during which compositional alteration is likely to occur, such as reduction of beneficial glucosinolates. Senescence has also been referred as having a similar effect due to transportation of glucosinolates out of plant tissue or to degradation by myrosinases and release as volatiles. ${ }^{10}$ Thus, conditions at harvest and post-harvest must be under control to avoid this degradation process, since it is known that the hydrolytic activity of myrosinase differs within plant tissue and is higher in young tissues of the plant. ${ }^{11}$ Refrigerated storage and controlled atmosphere have been shown to increase levels of thiocyanate ion, volatile isothiocyanates and goitrin ${ }^{12,13}$ in cabbage, declining after senescence of the inflorescence. An increase in pungency, mustiness and bitterness was shown in white cabbage stored in controlled atmosphere, however, this was not related to glucosinolate levels. ${ }^{14,15}$ An increase in total glucosinolate content was reported in broccoli when stored under air or under controlled atmosphere for 7 days, until the beginning of deterioration, while the absence of $\mathrm{O}_{2}$ with a $20 \% \quad \mathrm{CO}_{2}$ concentration resulted in total glucosinolate decrease. ${ }^{16}$

\footnotetext{
* Correspondence to: Eduardo AS Rosa, Section of Horticulture, Department of Field Crops, Universidade de Trás-os-Montes e Alto Douro, Apartado 202, 5001 Vila Real Codex, Portugal 
Table 1. Significance for the total and individual glucosinolates of the five treatments in the main and secondary inflorescences

\begin{tabular}{|c|c|c|c|c|c|c|c|c|c|c|c|c|}
\hline \multirow[b]{2}{*}{ Source } & \multicolumn{12}{|c|}{ Glucosinolates } \\
\hline & 1 & 2 & 3 & 4 & 5 & 6 & 7 & 8 & 9 & 10 & 11 & Total \\
\hline Treatment & ns & $\star \star$ & $\star \star \star$ & * & ns & $\star \star \star *$ & $\star \star \star ~$ & 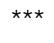 & 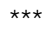 & $\star \star$ & $\star \star \star *$ & $\star \star \star ~$ \\
\hline Inflorescence & ns & $\star \star$ & $\star \star \star$ & * & $\star \star \star ~$ & $\star \star \star ~$ & $\star \star \star$ & ns & ns & $\star \star \star ~$ & ns & * \\
\hline Treatment $\times$ Inflorescence & ns & ns & * & ns & ns & $* \star \star$ & * & * & * & $* \star \star$ & * & $\star \star \star *$ \\
\hline
\end{tabular}

1, 3-methylsulphinylpropyl; 2, 2-hydroxybut-3-enyl; 3, 4-methylsulfinylbutyl; 4, 5-methylsulphinylpentyl; 5, But-3-enyl; 6, 4-hydroxyindol-3-ylmethyl; 7, 2-hydroxy2-phenylethyl; 8, Indol-3-ylmethyl; 9, 2-phenylethyl; 10, 4-methoxyindol-3-ylmethyl; 11, 1-methoxyindol-3-ylmethyl

ns, $p>0.05 ;{ }^{*} p<0.05 ;{ }^{* \star} p<0.01 ;{ }^{\star \star *} p<0.001$.

In this study we compared several situations to which broccoli might be submitted, either during or after harvest, and their effect on glucosinolate levels.

\section{MATERIALS AND METHODS \\ Plant}

Seeds of broccoli (Brassica oleracea var italica) cv 'Tokyodome' were sown at a $2.5 \mathrm{~cm}$ depth in polypropylene trays with alveoles of $65 \mathrm{~cm}^{3}$ filled with a peat compost (Humobact Terreau) and river sand in a proportion $\mathrm{v} / \mathrm{v}$ of $3: 1$. At 28 days after seeding, transplants were set in the experimental field of the University of Trás-os-Montes e Alto Douro, at an altitude of $453 \mathrm{~m}, 41^{\circ} 17^{\prime} \mathrm{N}$ and $7^{\circ} 44^{\prime} \mathrm{W}$ in a randomized complete block with three replicates. At commercial maturation stage, which occurred 57 days after planting, the main inflorescences of the plants of each replicate were harvested and combined to make a composite sample. Each lot was divided in four as follows: one was used immediately for analysis; another was left at room temperature $\left(20^{\circ} \mathrm{C}\right)$ for 5 days another was blanched for $1 \mathrm{~min}$ and immediately frozen and kept at $-20^{\circ} \mathrm{C}$, and in the fourth treatment, the inflorescences were kept in the refrigerator at $4{ }^{\circ} \mathrm{C}$ for 5 days. A fifth situation was leaving inflorescences on the plant and harvesting 5 days after the first harvest, corresponding to a post-maturation stage. The inflorescences from two plants were used per replicate and situation for glucosinolate analysis and the inflorescences from a third plant were dried in a forced-air oven (Memmert UL-80) at $65^{\circ} \mathrm{C}$ until a constant weight was achieved, to determine the dry weight. When the secondary inflorescences reached commercial maturation, they were harvested and submitted to the same situations described above for the main inflorescences.

\section{Analysis}

The extraction and analysis of the plant material was according to the current methods used in our laboratory ${ }^{17}$ of which the main steps are as follows. Inflorescences were freeze-dried and reduced to a fine powder, and $c 2 \mathrm{~g}$ of material were extracted in $90 \%$ boiling methanol for $2 \mathrm{~min}$ using a small centrifuge tube to which was added $0.2 \mathrm{ml}$ of benzyl glucosinolate (glucotropaeolin) $\left(1 \mathrm{mgml}^{-1}\right)$ as an internal standard. After centrifugation the supernatant was transferred to a $10 \mathrm{ml}$ flask. The residue was extracted twice in $70 \%$ boiling methanol for $1 \mathrm{~min}$, centrifuged and supernatant added to the same flask. The final volume was made to $10 \mathrm{ml}$ with water. A $2.5 \mathrm{ml}$ aliquot was evaporated to dryness and resuspended in a similar volume of pure water. A $2 \mathrm{ml}$ aliquot was added to a small Sephadex A25 column and desulphoglucosinolates were obtained after treatment of the column with sulphatase. ${ }^{18} \mathrm{~A}$ final volume of $1.5 \mathrm{ml}$ was recovered for HPLC analysis according to the method described by Spinks et al. ${ }^{19}$ An analysis of variance was performed to compare differences between treatments using a SuperAnova programme. Levels of glucosinolates are expressed in $\mu$ moles $\mathrm{kg}^{-1} \mathrm{DW}$.

\section{RESULTS AND DISCUSSION}

The glucosinolate pattern found in a fresh harvested broccoli inflorescence, which is shown in Table 1, is in agreement with other reports, ${ }^{16,20}$ however, there are differences in the relative content of glucosinolates probably due to the cultivar and growing conditions. Generally the five treatments have a significant effect on total and individual glucosinolates (Table 1). Similarly most of the individual glucosinolates and totals vary between inflorescence types (Table 1).

The major glucosinolates in the principal inflorescences of fresh harvested broccoli were 4-methylsulphinylbutyl- and indol-3-ylmethyl-, representing 52 and $27 \%$ of the total glucosinolate content, respectively. In the secondary inflorescences, the same glucosinolates accounted for $75 \%$ of the total content with 36 and $39 \%$, respectively. Large proportions of these glucosinolates were also reported by Hansen et $a l^{16}$ and Lewis et al. ${ }^{20}$ Other glucosinolates such as 3-methylsulphinylpropyl-, 2-hydroxybut-3-enyl-, but3-enyl-, 4-hydroxyindol-3ylmethyl- and 2-phenylethyl- were observed in negligible amounts (less than $100 \mu$ moles kg ${ }^{-1}$ DW).

\section{Total glucosinolates}

The highest total glucosinolate content was noted in the fresh inflorescences at commercial maturation with no difference between the principal and secondary inflorescences (Table 2) which was 20888 and $20355 \mu \mathrm{moles} \mathrm{kg}^{-1} \mathrm{DW}$, respectively. At post-maturation stage, there was a decrease of 12 and $44 \%$, respectively, in the total glucosinolate content in both 
Table 2. Glucosinolate levels ( $\mu$ moleskg ${ }^{-1} \mathrm{DW}$ ) in the principal $(\mathrm{P})$ and secondary $(\mathrm{S})$ inflorescences of broccoli 'Tokyodome' submitted to different treatments during 5 days

\begin{tabular}{|c|c|c|c|c|c|c|}
\hline \multirow[b]{2}{*}{ Glucosinolate } & \multirow[b]{2}{*}{ Inflorescence } & \multicolumn{5}{|c|}{ Treatment } \\
\hline & & Fresh material & Post-maturation & $\begin{array}{c}\text { Room } \\
\text { temperature } \\
\left(20^{\circ} \mathrm{C}\right)\end{array}$ & Fridge $\left(4^{\circ} \mathrm{C}\right)$ & $\begin{array}{l}\text { Blanched and } \\
\text { frozen }\left(-20^{\circ} \mathrm{C}\right)\end{array}$ \\
\hline 3-methylsulphinylpropyl- & $\begin{array}{l}P \\
S\end{array}$ & $\begin{array}{l}0 \pm 0 \mathrm{aA} \\
0 \pm 0 \mathrm{aA}\end{array}$ & $\begin{array}{l}0 \pm 0 \mathrm{aA} \\
0 \pm 0 \mathrm{aA}\end{array}$ & $\begin{array}{c}0 \pm 0 a A \\
24 \pm 24 a A\end{array}$ & $\begin{array}{c}0 \pm 0 \mathrm{aA} \\
12 \pm 12 \mathrm{aA}\end{array}$ & $\begin{array}{r}22 \pm 5 \mathrm{aA} \\
0 \pm 0 \mathrm{aA}\end{array}$ \\
\hline 2-hydroxybut-3-enyl- & $\begin{array}{l}P \\
S\end{array}$ & $\begin{array}{l}95 \pm 14 \mathrm{bA} \\
33 \pm 17 \mathrm{bA}\end{array}$ & $\begin{array}{c}9.6 \pm 2.3 \mathrm{bA} \\
0 \pm 0 \mathrm{bB}\end{array}$ & $\begin{array}{l}55 \pm 9 b A \\
60 \pm 7 a A\end{array}$ & $\begin{array}{l}60 \pm 7 b A \\
20 \pm 10 b A\end{array}$ & $\begin{array}{l}169 \pm 57 a A \\
109 \pm 14 a A\end{array}$ \\
\hline 4-methylsulphinylbutyl- & $\begin{array}{l}\mathrm{P} \\
\mathrm{S}\end{array}$ & $\begin{array}{r}10925 \pm 830 a A \\
7299 \pm 552 a B\end{array}$ & $\begin{array}{l}8307 \pm 1781 b A \\
4922 \pm 1163 a b B\end{array}$ & $\begin{array}{r}1948 \pm 336 c A \\
786 \pm 174 c A\end{array}$ & $\begin{array}{l}7539 \pm 232 b A \\
6566 \pm 202 a A\end{array}$ & $\begin{array}{c}10101 \pm 1360 \mathrm{aA} \\
3781 \pm 460 \mathrm{bB}\end{array}$ \\
\hline 5-methylsulphinylpentyl- & $\begin{array}{l}\mathrm{P} \\
\mathrm{S}\end{array}$ & $\begin{array}{l}230 \pm 7 a A \\
223 \pm 6 a A\end{array}$ & $\begin{array}{l}146 \pm 25 \mathrm{aA} \\
109 \pm 22 \mathrm{bA}\end{array}$ & $\begin{array}{c}191 \pm 109 a A \\
76 \pm 19 b B\end{array}$ & $\begin{array}{l}150 \pm 10 a A \\
137 \pm 7 a A\end{array}$ & $\begin{array}{l}249 \pm 20 a A \\
162 \pm 16 a A\end{array}$ \\
\hline But-3-enyl- & $\begin{array}{l}\mathrm{P} \\
\mathrm{S}\end{array}$ & $\begin{array}{l}50 \pm 8 \mathrm{aA} \\
13 \pm 13 \mathrm{aB}\end{array}$ & $\begin{array}{c}36 \pm 12 \mathrm{bA} \\
0 \pm 0 \mathrm{aB}\end{array}$ & $\begin{array}{r}66 \pm 3 a A \\
0 \pm 0 a B\end{array}$ & $\begin{array}{r}41 \pm 2 \mathrm{bA} \\
0 \pm 0 \mathrm{aB}\end{array}$ & $\begin{array}{r}32 \pm 8 \mathrm{bA} \\
0 \pm 0 \mathrm{aB}\end{array}$ \\
\hline $\begin{array}{l}\text { 4-hydroxyindol-3- } \\
\text { ylmethyl- }\end{array}$ & $\begin{array}{l}P \\
S\end{array}$ & $\begin{array}{c}57 \pm 3 a A \\
107 \pm 11 c d A\end{array}$ & $\begin{array}{r}44 \pm 11 \mathrm{aA} \\
176 \pm 46 \mathrm{cB}\end{array}$ & $\begin{array}{l}124 \pm 12 \mathrm{aA} \\
492 \pm 37 \mathrm{aB}\end{array}$ & $\begin{array}{c}38 \pm 1 \mathrm{aA} \\
351 \pm 89 \mathrm{bB}\end{array}$ & $\begin{array}{l}61 \pm 17 \mathrm{aA} \\
60 \pm 31 \mathrm{dA}\end{array}$ \\
\hline 2-hydroxy-2-phenylethyl- & $\begin{array}{l}P \\
S\end{array}$ & $\begin{array}{r}111 \pm 15 \mathrm{bA} \\
18 \pm 18 \mathrm{bB}\end{array}$ & $\begin{array}{c}46 \pm 23 c A \\
0 \pm 0 b A\end{array}$ & $\begin{array}{l}201 \pm 9 a A \\
127 \pm 16 a B\end{array}$ & $\begin{array}{c}0 \pm 0 \mathrm{cA} \\
18 \pm 18 \mathrm{bA}\end{array}$ & $\begin{array}{c}27 \pm 27 \mathrm{cA} \\
0 \pm 0 \mathrm{bA}\end{array}$ \\
\hline Indol-3-ylmethyl- & $\begin{array}{l}\mathrm{P} \\
\mathrm{S}\end{array}$ & $\begin{array}{l}5573 \pm 438 a A \\
7967 \pm 987 a B\end{array}$ & $\begin{array}{l}5134 \pm 765 \mathrm{aA} \\
3388 \pm 547 \mathrm{cB}\end{array}$ & $\begin{array}{l}457 \pm 137 b A \\
893 \pm 270 d A\end{array}$ & $\begin{array}{l}5695 \pm 432 \mathrm{aA} \\
6189 \pm 358 \mathrm{bA}\end{array}$ & $\begin{array}{l}5264 \pm 167 a A \\
5151 \pm 635 b A\end{array}$ \\
\hline 2-phenylethyl- & $\begin{array}{l}P \\
S\end{array}$ & $\begin{array}{l}78 \pm 8 b A \\
46 \pm 23 b A\end{array}$ & $\begin{array}{r}71 \pm 4 \mathrm{bA} \\
0 \pm 0 \mathrm{bA}\end{array}$ & $\begin{array}{l}393 \pm 96 a A \\
719 \pm 163 a B\end{array}$ & $\begin{array}{l}69 \pm 3 b A \\
22 \pm 22 b A\end{array}$ & $\begin{array}{r}60 \pm 2 \mathrm{bA} \\
0 \pm 0 \mathrm{bA}\end{array}$ \\
\hline $\begin{array}{l}\text { 4-methoxyindol-3- } \\
\text { ylmethyl- }\end{array}$ & $\begin{array}{l}P \\
S\end{array}$ & $\begin{array}{l}1396 \pm 78 \mathrm{aA} \\
1756 \pm 159 \mathrm{cA}\end{array}$ & $\begin{array}{l}1479 \pm 184 a A \\
1414 \pm 349 c A\end{array}$ & $\begin{array}{r}782 \pm 107 \mathrm{bA} \\
3237 \pm 422 \mathrm{aB}\end{array}$ & $\begin{array}{l}1403 \pm 126 \mathrm{aA} \\
2582 \pm 55 \mathrm{bB}\end{array}$ & $\begin{array}{l}1244 \pm 92 \mathrm{aA} \\
1331 \pm 135 \mathrm{cA}\end{array}$ \\
\hline $\begin{array}{l}\text { 1-methoxyindol-3- } \\
\text { ylmethyl- }\end{array}$ & $\begin{array}{l}P \\
S\end{array}$ & $\begin{array}{l}2473 \pm 338 a A \\
2893 \pm 707 a A\end{array}$ & $\begin{array}{l}3015 \pm 308 \mathrm{aA} \\
1437 \pm 272 \mathrm{bB}\end{array}$ & $\begin{array}{c}129 \pm 33 b A \\
1016 \pm 316 b A\end{array}$ & $\begin{array}{l}2612 \pm 413 a A \\
3682 \pm 378 a A\end{array}$ & $\begin{array}{l}3025 \pm 260 a A \\
2852 \pm 522 a A\end{array}$ \\
\hline Total & $\begin{array}{l}\mathrm{P} \\
\mathrm{S}\end{array}$ & $\begin{array}{l}20888 \pm 971 a A \\
20355 \pm 1390 a A\end{array}$ & $\begin{array}{l}18372 \pm 823 a A \\
11445 \pm 2243 b B\end{array}$ & $\begin{array}{l}4347 \pm 457 \mathrm{bA} \\
7428 \pm 1327 \mathrm{cA}\end{array}$ & $\begin{array}{l}17606 \pm 573 a A \\
19579 \pm 498 a A\end{array}$ & $\begin{array}{l}20255 \pm 1250 a A \\
13446 \pm 1383 b B\end{array}$ \\
\hline
\end{tabular}

Lower case letters represent comparisons between the 5 treatments (compare within row); capitals represent comparisons between the 2 inflorescences (compare pair of values within each column)

Means with the same letters did not show significant differences $(P<05)$

type of inflorescences (Table 2). When inflorescences were kept refrigerated at $4{ }^{\circ} \mathrm{C}$ for 5 days the decrease in total glucosinolates was 16 and $4 \%$, respectively, for the principal and secondary inflorescences, when compared to the fresh harvested material at the commercial maturation stage. Freezing did significantly reduce the levels of the total glucosinolates in the principal inflorescences whilst, in the secondary inflorescences, the decrease was significant $(P<0.05)$ (Table 2).

The highest decrease in total glucosinolate content was observed when the fresh material was left at room temperature $\left(20^{\circ} \mathrm{C}\right)$ for 5 days (Table 2$)$. Thus it is likely that myrosinase was active during that time reducing glucosinolate levels with production of volatile and non-volatile degradation products. Other studies revealed the increased production of thiocyanate ion, volatile isothiocyanates and goitrin in cabbage even when stored under refrigerated storage and controlled atmosphere. ${ }^{12,13}$ Thus, in our study, conditions for endogenous hydrolysis might have been more favourable either due to the onset of senescence of the inflorescence or to more mild temperatures after harvest.

Although there was a reference ${ }^{16}$ describing an increase in total glucosinolate content explained by enhanced synthesis or a release of bound compounds during storage, in our study it seemed that the plant material is on the verge of senescence, characterised by dehydration or by yellowing of the florets.

\section{Individual glucosinolates}

There were significant differences $(P<0.001)$ in the levels of 4-methylsulphinylbutyl glucosinolate between treatments in the principal and in the second inflorescences. The levels in the principal inflorescences were generally higher $(P<0.05)$ than in the secondary inflorescences, the smaller differences being noted when the plant material was kept refrigerated, while the largest was noted for the frozen material (Table 2). No significant differences were noted in 4methylsulphinylbutyl glucosinolate content between the fresh harvested material and frozen material for the principal inflorescence. Keeping the principal inflor- 
escences at $4{ }^{\circ} \mathrm{C}$ reduced 4-methylsulphinylbutylcontent by $31 \%$, while at room temperature the reduction was $82 \%$. In the secondary inflorescences the largest reduction was also at room temperature (89\%), followed by the frozen material (48\%).

Levels of indol-3-ylmethyl glucosinolate tended to be higher in the secondary inflorescences except when inflorescences were harvested at post-maturation stage and when frozen (Table 2). Apart from the extremely low levels of indol-3-ylmethyl glucosinolate in the inflorescences at room temperature, no significant differences $(P<0.05)$ were noted in the levels for the main inflorescence for the other treatments. On the other hand, and in the secondary inflorescences, treatments differ significantly $(P<0.001)$ with large decreases in the post-matured material (57\%) and room temperature (89\%); the decrease in indol-3ylmethyl glucosinolate in the inflorescences kept in the fridge was lower (22\%) than when frozen $(35 \%)$. This difference could be due to blanching prior to freezing which might leach out this thermolabile glucosinolate. $^{21}$ The loose structure of the broccoli stalk and flower head, which appears to be very susceptible to the leaching effects, ${ }^{22}$ and the water blanching used in our study might have contributed to higher losses. Frozen broccoli is expected to have a lower effect on the metabolisation of foreign compounds due to a reduction in the activity of the mixed-function oxidase (MFO) enzyme system by blanching, a process which inactivates myrosinase $\mathrm{e}^{23}$ and consequentely reduces the release of the beneficial hydrolysis products of the indole glucosinolates. ${ }^{24}$ A similar effect was reported for cooked cabbage. ${ }^{24}$ The presence of active myrosinase has been claimed to be essential for the capacity of glucosinolates from broccoli to induce the activity of several cytochrome P-450 isoenzymes. ${ }^{25}$ Thus, despite inactivation of myrosinase by blanching the release of those beneficial hydrolysis products might be guaranted by myrosinase activity found in certain intestinal microflora which could be important when intact glucosinolates are digested. ${ }^{26}$

The other indole glucosinolate, 1-methoxyindol-3ylmethyl-, followed the same trend as the indol-3ylmethyl glucosinolate between the two inflorescence types, despite relative differences in levels (Table 2). In the principal inflorescences, there were no significant differences between treatments except when exposed to room temperature ( $95 \%$ reduction). Levels in the secondary inflorescences kept at $4{ }^{\circ} \mathrm{C}$ were higher (but not significantly) than the fresh material and levels were unchanged by freezing. There was a $65 \%$ loss of 1-methoxyindol-3-ylmethyl- on storage at room temperature and post-mature material also had significantly lower levels.

The 4-methoxyindol-3-ylmethyl glucosinolate also followed the trend of the previous indoles with respect to relative differences between principal and second inflorescences. In the principal inflorescences, the lowest levels were noted when material was exposed to room temperature, which differs significantly
$(P<0.05)$ from the other treatments which did not show significant differences (Table 2). On the other hand, and in the second inflorescences, levels of 4methoxyindol-3-ylmethyl glucosinolate were the highest when kept at room temperature followed by the situation when stored the refrigerator.

\section{CONCLUSIONS}

The main source of glucosinolates in broccoli is the principal inflorescence followed by the secondary inflorescences, except for the indole group. The harvest of broccoli must be done at the full commercial stage to reach the highest levels of glucosinolates, and, from that developmental stage onwards, the inflorescence is under critical situations with respect to quality. These results indicate that the levels of glucosinolates and the beneficial properties of broccoli might be lost if not stored under suitable conditions. Freezing is the best method for preserving the glucosinolate content although, to avoid degradation of indole glucosinolates during blanching, refrigeration at $4{ }^{\circ} \mathrm{C}$ is the best procedure.

\section{ACKNOWLEDGEMENTS}

The authors would like to thank the British Council for the financial support which facilitated completion of this work.

\section{REFERENCES}

1 Verhoeven DTH, Goldbohm RA, Poppel G, Verhagen H and Brandt PA, Epidemiological studies on Brassica vegetables and cancer risk. Cancer Epid, Biom Prev, 5:733-748 (1996).

2 Steinmetz KA and Potter JD, Vegetables, fruit, and cancer. II. Mechanisms. Cancer Causes and Control 2:427-442 (1991).

3 Clapper ML, Szarka CE, Pfeiffer GR, Graham TA, Balshem AM, Litwin S, Goosenberg EB, Frucht $\mathrm{H}$ and Engstrom PF, Preclinical and clinical evaluation of broccoli supplements as inducers of glutathione S-transferase activity. Clin Cancer Res 3:25-30 (1997).

4 Friedman AA, Anti-cancer effect of broccoli: selective inhibition of transformed mammalian cell growth by Brassica oleracea extract. F Mississipi Acad Sci 42:159-164 (1997).

5 Heather DW, Sieczka JB, Dickson MH and Wolfe DW, Heat tolerance and holding ability in broccoli. 7 Amer Soc Hort Sci 117:887-892 (1992).

6 Fahey JW and Talalay P, The role of crucifers in cancer chemoprotection, in Phytochemicals and Health, Ed by Gustine DL and Flores HE, American Society Plant of Physiologists, Rockville, Md, pp 87-93 (1995).

7 Dufault RJ, Dynamic relationships between field temperatures and broccoli head quality. $\mathcal{F}$ Amer Soc Hort Sci 121:705-710 (1996).

8 Talalay P, Fahey JW, Holtzclaw WD, Prestera T and Zhang Y, Chemoprotection against cancer by phase 2 enzyme induction. Toxicol Lett 82/83:173-179 (1995).

9 Rosa EAS, Heaney RK, Fenwick GR and Portas CA, Glucosinolate in crop plants. Hort Rev 19:99-215 (1997).

10 Fieldsend J and Milford GFJ, Changes in glucosinolates during crop development in single- and double-low genotypes of winter oilseed rape (Brassica napus): II. Profiles and tissuewater concentrations in vegetative tissues and developing pods. Ann Appl Biol 124:543-555 (1994). 
11 Bones AM, Distribution of $\beta$-thioglucosidase activity in intact plants, cell and tissue cultures and regenerant plants of Brassica napus L. F Exp Bot 41:737-744 (1990).

12 Chong C and Berard LS, Changes in glucosinolates during refrigerated storage of cabbage. F Amer Soc Hort Sci 108:688691 (1983).

13 Berard L and Chong C, Influences of storage on glucosinolate fluctuations in cabbage. Acta Hort 157:203-210 (1985).

14 Hansen $\mathrm{H}$, Organoleptic evaluation of white cabbage stored in commercial storage rooms at different level of $\mathrm{CO}_{2}$. Acta Hort 93:29-44 (1979).

15 Toivonen P, Walsh J, Lougheed EC and Murr DP, Ethylene relationships in storage of some vegetables, in Controlled Atmospheres for Storage and Transport of Perishable Agricultural Commodities, Ed by Richardson DG and Meherivk M, Oregon State Univ Symp Ser 1, Timber Press, Oregon, pp 299-307 (1982).

16 Hansen M, Møller P, Sørensen H and de Trejo MC, Glucosinolate in broccoli stored under controlled atmosphere, f Amer Soc Hort Sci 120:1069-1074 (1995).

17 Rosa EAS, Daily variation in glucosinolate concentrations in the leaves and roots of cabbage seedlings in two constant temperature regimes. F Sci Food Agric 73:364-368 (1997).

18 Heaney RK and Fenwick GR, Glucosinolates in Brassica vegetables. Analysis of 22 varieties of Brussels sprouts (Brassica oleracea var gemmifera). F Sci Food Agric 31:785-793 (1980).

19 Spinks A, Sones K and Fenwick GR, The quantitative analysis of glucosinolates in cruciferous vegetables, oilseeds and forage crops using high performance liquid chromatography. Fette Seifen Anstrichmittel 86:228-231 (1984).
20 Lewis J, Fenwick GR and Gray AR, Glucosinolates in Brassica vegetables: green-curded cauliflowers (Brassica oleracea L. botrytis group) and purple-headed broccoli (B. oleracea L. italica group). Lebensm-Wiss u-Technol 24:361-363 (1991).

21 Rosa EAS and Heaney RK, The effect of cooking and processing on the glucosinolate content: studies on four varieties of Portuguese cabbage and hybrid white cabbage. I Sci Food Agric 62:259-265 (1993).

22 Goodrich RM, Anderson JL and Stoewsand GS, Glucosinolate changes in blanched broccoli and Brussels sprouts. $\mathcal{F}$ Food Proc Preser 13:275-280 (1989).

23 Björkman $\mathrm{R}$ and Lönnerdal B, Studies on myrosinase, III: enzymatic properties of myrosinases from Sinapis alba and Brassica napus seeds. Biochem Biophys Acta 327:121-131 (1973).

24 McDanell R, McLean AEM, Hanley AB, Heaney RK and Fenwick GR, Differential induction of mixed-function oxidase (MFO) activity in rat liver and intestine by diets containing processed cabbage: correlation with cabbage levels of glucosinolates and glucosinolate hydrolysis products. Food Chem Toxic 25:363-368 (1987).

25 Loft S, Otte J, Poulsen HE and Sørensen H, Influence of intact and myrosinase-treated indolyl glucosinolates on the metabolism in vivo of metronidazole and antipyrene in the rat. Food Chem Toxic 30:927-935 (1992).

26 Verhoeven DTH, Verhagen H, Goldbohm RA, Brandt PA and Poppel G, A review of mechanisms underlying anticarcinogenicity by brassica vegetables. Chemico-Biological Interactions 103:79-129 (1996). 